Criaciàs: Critica

\title{
Opressäa e resistencia na cozinha em Como água para chocolate, de Laura Esquivel
}

Jenison Alisson Santos

\author{
Ana Cristina Marinho Lúcio
}

Resumo: O presente artigo objetiva analisar a representação do espaço da cozinha em Como água para chocolate (I993) de Laura Esquivel e suas implicações nos movimentos de opressão e resistência caracterizados pela autora em sua diegese. Tita De la Garza, ao nascer sobre a mesa da cozinha, é destituída de uma vivência plena ao ser subjugada por uma tradição familiar que a coloca na posição de servente de sua mãe até o fim de seus dias. A cozinha, que num primeiro momento se mostra como um lugar de confinamento, ressignifica-se como um eixo subversivo de formação de subjetividades femininas uma vez que Tita encontra no aprisionamento espacial uma forma de projetar sua voz, desejos e sentimentos silenciados através da comida. Apoiamo-nos em teóricos a exemplo de Tuan (2013), Sceats (2003) e Certeau, Giard e Mayol (1996) para melhor compreender como isso se desdobra no romance.

Palavras-chave: Laura Esquivel; como água para chocolate; espaço; cozinha; opressão; resistência.

AвSTRACT: This paper aims to analyse the kitchen space representation in Como água para chocolate (I993) by Laura Esquivel and its implications for the movements of oppression and resistance portrayed by the author in the diegesis. Tita De la Garza, born over the kitchen table, is deprived of living a meaningful life to fulfill a family tradition in order to take care of her mother until her death. The kitchen, at first stablished as a place of confinement, is transformed into a subversive axis for the development of female subjectivities as Tita finds in her spatial imprisonment a way to project her once silenced voice, desires, and feelings through food. In order to better understand how this movement develops in the novel, we base our theoretical framework on scholars such Tuan (2013), Sceats (2003), and Certeau, Giard and Mayol (I996). KEYwords: Laura Esquivel; como água para chocolate; space; kitchen; oppression; resistance.

O espaço, seja ele físico ou ficcional, configura-se como um âmbito em que são possibilitadas ao sujeito suas vivências e experiências "das quais uma pessoa conhece e constrói a realidade" (TUAN, 20I3, p. I7). Tal espaço, entretanto, está sujeito a ser sistematizado a partir de uma ótica masculina que, manifestada em uma sociedade inerentemente dominada por uma perspectiva falocêntrica, é estabelecida como sendo espontânea e genuína. Essa ótica está imbuída no corpo social de tal forma que se manifesta de maneira significativa no que se refere à distribuição de ocupações, funções e, consequentemente, de espaços calcados na dicotomia masculino/feminino. Essa ordem social, segundo Pierre Bourdieu,

funciona como uma imensa máquina simbólica que tende a ratificar a dominação masculina sobre a que se alicerça: é a divisão social do trabalho, distribuição bastante estrita das atividades atribuídas a cada um dos dois sexos [...]; é a estrutura do espaço, opondo o lugar de assembleia ou de mercado, reservados aos homens, e a casa, reservada às mulheres; ou no interior desta, entre a parte masculina, com o salão, e a parte feminina, com o estábulo, a água e os vegetais [...]. (BOURDIEU, 2015, p. I8)

Nessa perspectiva, dado que o espaço privado - em especial o da cozinha - é comumente imbuído de marcas de estereótipos machistas e opressores que destituem o sujeito

1 Mestrando do Curso de Pós-Graduação em Letras da Universidade Federal da Paraíba e bolsista CAPES. Contato: jenison.alisson@gmail.com.

2 Professora Adjunta da Universidade Federal da Paraíba, atuando no Departamento de Letras Clássicas e Vernáculas e no Programa de Pós-Graduação em Letras. Contato: anamanho@gmail.com. 
mulher de uma validação plena na sociedade, concedendo a esse sujeito uma realidade permeada pela opressão sistematizada calcada pelo confinamento do lar, nos chama a atenção que a autora mexicana Laura Esquivel tenha escolhido tal espaço para o seu primeiro romance, Como água para chocolate (1993), primeiramente publicado em 1989. Como não é possível falar sobre o espaço da cozinha sem trazer à tona o que nele é produzido - a comi$\mathrm{da}-$, a autora estrutura o seu romance como um livro de receitas, contemplando doze pratos representativos de doze meses na vida de Tita De la Garza, demonstrando como cada iguaria teve papel fundamental nos acontecimentos que se desdobram em cada capítulo. Se num primeiro momento Como água para chocolate - considerado um marco da literatura feminista mexicana (SANDOVAL, 2008) - causa questionamentos, visto que a protagonista da narrativa é confinada no espaço da cozinha por sua mãe na intenção de concretizar uma tradição familiar que compete a Tita, por ser a mais nova das filhas, servir a matriarca dos De la Garza até o dia de sua morte, o leitor logo poderá perceber que "Esquivel fez da cozinha um lugar libertador para as mulheres" " (SANDOVAL, 2008, p. 59), um lugar propício para dar voz aos silenciados, para a emergência da subversão e para o empoderamento feminino, fazendo com que Como água para chocolate mereça o seu destaque no âmbito dos estudos feministas.

Iniciaremos nosso percurso analítico apresentando a relação entre Esquivel e o espaço da cozinha. Em seguida, apresentaremos nossa fundamentação teórica em consonância ao texto literário, propiciando ver tal espaço como possível de ressignificar tradições, desconstruir paradigmas socioculturais, questionar o poder opressor sistemático do patriarcado e promover a potência do sujeito feminino através do que se refere ao espaço culinário em Como água para chocolate.

\section{Laura Esquivel e a receita para una cozinha gubsersiva}

Nascida na Cidade do México em 1950, Laura Esquivel é um tour de force do cenário artístico mexicano. Professora, roteirista de tv, cinema e peças teatrais e escritora de narrativas literárias, Esquivel sempre teve nas mulheres de sua família uma forte influência - o que fomentou a sua natureza subversiva desde os primeiros anos de vida, especialmente no que diz respeito ao espaço da cozinha como um lugar de transgressão. Em uma entrevista concedida ao The New York Times, a autora afiança:

[...] minha avó morava do outro lado da rua numa casa velha que foi construída quando igrejas eram ilegais no México. [...] Ela possuía uma capela em casa, que ficava entre a cozinha e a sala de jantar. O cheiro de nozes e pimenta e alho se

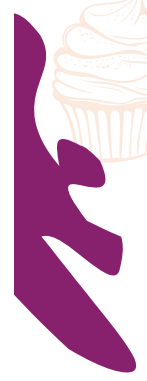

"Esquivel has made the kitchen the liberating space of women". Tradução nossa, assim como as demais presentes no texto e não referenciadas na bibliografia. 
misturavam aos cheiros que vinham da capela, [...] dos óleos e das ervas curandeiras" (O’NEILL, I993).

Passados os primeiros anos de sua infância, junto a avó e a mãe, entre o fogo e os aromas da cozinha, onde escutava "[...] todo tipo de histórias, mas acima de tudo, histórias de mulheres" ${ }^{5}$ (ESQUIVEL, 20I4, p. I5), a autora desenvolve durante a juventude uma relação conflitante com tal espaço. Se por um lado, na infância esse ambiente lhe proporcionava um elo afetivo entre as mulheres de sua vida, promovendo uma relação de identidade e memória, por outro, a adolescência mostrava que a cozinha se configurava como um lugar de confinamento onde não era permitido ampliar sua visão de mundo.

Essa transição se deu não apenas porque Esquivel estava contemplativa em relação à sua formação e contribuição para a sociedade (ESQUIVEL, 20I4), mas também porque ela vivia em um período de mudanças que iriam interferir no destino das mulheres no país:

Muitas de nós participamos durante os anos sessenta na consolidação da luta que outras mulheres haviam iniciado no início do século. Sentíamos que as urgentes mudanças sociais que se faziam necessárias naquele momento iriam acontecer fora de casa. [...] Não havia tempo a perder, muito menos na cozinha (ESQUIVEL, 20I4, p. I6-7).

A luta a qual Esquivel se refere em seu livro de ensaios, Íntimas suculencias (2014), foi o pontapé da luta feminista no México no final dos anos sessenta. De acordo com Sandoval (2008), as mulheres - - em sua grande maioria, estudantes - fizeram uso de sua condição de sujeitos fora da discussão política do país para obter visibilidade em locais onde não era permitida a passagem de civis, clamando por mudanças no cenário sociopolítico do país, em especial no que dizia respeito aos direitos das mulheres.

Em sua vida adulta, entretanto, após se casar e tornar-se mãe, Esquivel percebe que sua visão sobre o espaço na cozinha estava um tanto equivocada: a cozinha pode ser - e é - também um lugar político. Ao entrar em contato com suas raízes, visando oferecer à filha as mesmas experiências recebidas de suas matriarcas, a autora percebe que as histórias de mulheres que ela ouvia eram histórias de luta, de resistência, de potência feminina (ESQUIVEL, 20I4) como aquelas que ela vivenciou em sua juventude, configurando os momentos ao fogão como uma oportunidade de cozinhar, de amar e de politizar.

Esquivel formou-se como professora na Escuela Normal de Maestros. Após oito anos lecionando, passa a escrever peças infantis para seus alunos. Em 1986, com o incentivo do seu então marido Alfonso Arau (diretor da adaptação audiovisual de Como água para chocolate), Esquivel escreve seu primeiro roteiro para o cinema - Chido Guan, el tacos de oro.

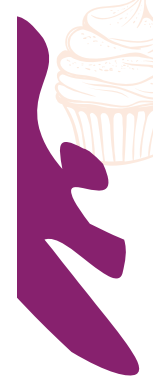

4 “[...] my grandmother lived across the street in an old house that was built when churches were illegal in Mexico," [...] She had a chapel in the home, right between the kitchen and dining room. The smell of nuts and chilies and garlic got all mixed up with the smells from the chapel, [...] the liniments and healing herbs".

"[escuché] todo tipo de historias, pero sobre todo, historias de mujeres"

6 "Muchas de nosotras participamos durante los años sesenta em la consolidación de la lucha que otras mujeres ya habían iniciado a principios de siglo. Sentíamos que los urgentes cambios sociales que se necesitaban en ese momento se iban a dar fuera de casa. [...] No había tempo que perder, mucho menos en la cocina" 
Em I989 a autora lança o que viria a ser um dos maiores fenômenos da literatura feminina contemporânea, Como água para chocolate, aclamado pela crítica e pelos leitores do mundo, sendo traduzido para mais de trinta idiomas. A autora mexicana tem recebido grande notoriedade da comunidade literária internacional, sendo, por exemplo, o(a) primeiro(a) escritor(a) estrangeiro(a) a ganhar o Prêmio ABBY (American Bookseller of the Year), em 1993. Desde então, Esquivel se firmou na literatura em nível internacional com outros romances de grande impacto, como Tão veloz quanto o desejo (200I), A lei do amor (1996) - considerada obra pioneira na utilização de recursos intermidiáticos como ferramenta para a estruturação da narrativa -, e o seu último romance publicado no Brasil, Malinche (2007).

Ambientado em cenário rural durante a Revolução Mexicana no início do século XX, Como água para chocolate é o relato da vida e da morte de Tita De la Garza que, por ser a filha mais nova, tem o seu destino selado pela tradição familiar de cuidar da sua mãe até o fim dos seus dias. Por esta razão, Mamãe Elena a coloca sob os cuidados das cozinheiras, Nacha e Chencha, onde Tita encontra a nutrição afetiva e desenvolve sua sensibilidade para com a comida no lugar a que havia sido condenada ao isolamento. A narrativa acompanha a vida da protagonista Tita por doze meses: cada mês corresponde a um dos doze capítulos do romance e a uma das doze receitas culinárias que abrem tais capítulos e que serão o cerne para os acontecimentos neles relatados. No romance de Esquivel, o leitor é convidado a acompanhar Tita na busca pela produção de suas subjetividades através da relação com o alimento e com o espaço da cozinha, processos que produzem dobras identitárias num corpo silenciado e marginalizado, criado e sentenciado para ser servil ao lar.

Problematizar teoricamente uma narrativa que contempla como eixo central o espaço da cozinha, metaforizado como lugar de experiências do feminino e de um devir-revolucionário, é também contemplar a produção subjetiva presente nas personagens enquanto processos de produções identitárias. Muito mais do que reificar as mulheres como naturalmente confinadas ao âmbito do privado, mais precisamente ao espaço da cozinha, Esquivel produz uma reinvenção subjetiva que implode com a noção de identidade tradicional atribuída à mulher por uma tradição patriarcal e falocêntrica, trabalhando o feminino a partir das várias maneiras em que as identidades são formadas e transformadas em relações às formas pelas quais são representadas e/ou interpeladas pela cultura e pela história. Assim sendo, as figurações literárias das personagens femininas de Esquivel produzem uma variedade de posições de sujeito para o feminino, confluindo com aquilo que é posto por Woodward (2000), ao estabelecer uma crítica à noção de identidade do sujeito moderno, pensado como ontologia e como um dado da natureza, demonstrando tanto a importância política quanto existencial presente nas composições identitárias das subjetividades, a saber:

A subjetividade envolve nossos sentimentos e pensamentos mais pessoais. Entre-

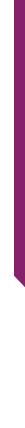

e a cultura dão significado à experiência que temos de nós mesmos e no qual nós adotamos uma identidade. Quaisquer que sejam os conjuntos de significados construídos pelos discursos, eles só podem ser eficazes se eles nos recrutam como sujeitos. Os sujeitos, são, assim, sujeitados ao discurso e devem, eles próprios, assumi-lo 
como indivíduos que, dessa forma, se posicionam a si próprios. As posições que assumimos e com as quais nos identificamos constituem nossas identidades (WOODWARD, 2000, p. 55).

Woodward, em seu texto Identidade e diferenças (2000), implode com a noção de identidade como essência ou como parte da natureza, mostrando que tanto a identidade quanto a diferença são produzidas, não sendo criaturas do mundo natural ou transcendental, enfatizando-as enquanto construtos culturais e sociais e demarcando as identidades e as subjetividades como criadas por meio de atos de linguagem. Tomando como ponto de partida essa assertiva, podemos questionar: como o confinamento (confinamento que se estende ao espaço privado, ao círculo familiar, ao corpo feminino) tratado em Como água para chocolate vai influenciar na produção de novas formas de subjetivação do sujeito? Assim sendo, também problematizamos: como se constrói o processo de subjetivação feminina a partir das relações de poder na composição narrativa de Esquivel, compreendendo sua dimensão política e de gênero - levando em conta, também, o dado gastronômico presente na obra? É o que veremos na análise a seguir.

\section{Cozinha de opressäo, cozinha de resistência}

Em 1928, quando Virginia Woolf profere em Newnhan College e em Girton College o ensaio Um teto todo seu (20I4), a autora afiança de forma revolucionária que a mulher necessita de seu espaço próprio para que sua sensibilidade artística e competência intelectual sejam libertas das amarras da opressão patriarcal ${ }^{7}$. Entretanto, Woolf não cogita que o espaço da cozinha possa oferecer tal emancipação. Ao questionar o que faz a mulher da sua contemporaneidade, a autora indaga: "E se alguém lhe perguntasse [...] o que a senhora estava fazendo em 5 de outubro de 1868 [...], ela ficaria insegura e diria que não consegue se lembrar de nada. Pois todos os jantares foram preparados; os pratos e copos, lavados [...]. Disso tudo, nada permaneceu" (WOOLF, 2014, p. 128).

Se por um lado, no cenário europeu contemporâneo de Woolf “[...] chefs ainda eram homens de prestígio a serem admirados e lisonjeados" ${ }^{8}$ (HALEY, 2013, p. 217), podemos perceber a partir da indagação da autora inglesa que a cozinha representava para o sujeito feminino um suposto espaço do efêmero e vazio de propósitos socialmente significativos, configurando-se num lugar associado a atividades reincidentes e exaustivas, de onde nada de relevante se materializa - afinal, "até a costura ou a cozinha, práticas costumeiras das mulheres, precisam tornar-se masculinas para serem 'alta' (a alta costura) ou 'grande' (a grande cozinha)" (PERROT, 2007, p. 97). Ainda sobre os afazeres domésticos - mais precisamente relacionados ao âmbito da cozinha - Woolf, no seu artigo intitulado Mulheres romancistas (2015), assegura que essas atividades se caracterizam como uma obstrução da 
potencialidade da criatividade do sujeito mulher uma vez que, por exemplo, "[...] Charlotte Brontë teria de interromper o trabalho para ir descascar batatas" (WOOLF, 20I5, p. 27).

Apesar do homem dominar o cenário gastronômico enquanto profissão respeitada (HALEY, 20I3), a atividade de cozinhar no âmbito privado foi outorgada como uma atividade feminina, visto que foi construída no ideário de uma sociedade patriarcal que essa mulher supostamente possui habilidades imanentes à sua condição de exercer com aptidão tal tarefa. Não obstante, depois de mais de um século após o discurso de Woolf, as estudiosas e os estudiosos feministas ainda contestam esse lugar-comum que reproduz a marginalização e limitação da mulher em função da inserção no espaço público. Podemos tomar como exemplo a fala da autora nigeriana Chimamanda Ngozi Adichie (20I5), ao refletir sobre a diferenciação exacerbada entre os gêneros que é perpetuada pela sociedade:

Ainda hoje, as mulheres tendem a fazer mais tarefas de casa do que os homens - elas cozinham e limpam a casa. Mas porque é assim? Será que elas nascem com um gene a mais para cozinhar ou será que [...] elas foram condicionadas a entender que seu papel é cozinhar? Cheguei a pensar que talvez as mulheres de fato houvessem nascido com tal gene, mas aí lembrei que os cozinheiros mais famosos do mundo - que recebem o título pomposo de "chef" - são, em sua maioria, homens (ADICHIE, 20I5, p. 37).

Compreendemos, a partir do posicionamento das autoras acima, que esperar que a mulher seja a responsável pelos afazeres domésticos é algo inerente à cultura patriarcal ocidental que perpetua o velho e cansado chavão machista de que "o lugar da mulher é na cozinha”. Este fenômeno se desdobra, inclusive, na produção artística das mulheres, já que por se encontrarem numa posição em que são “[...] limitadas por definições sexuais e de gênero que não se deixam desconstruir ou reconstruir livremente dentro da sociedade patriarcal [...]" (SCHNEIDER, L., 2006, p. I49) estas, consequentemente, são confinadas no espaço doméstico (aqui incluindo a cozinha), evidenciando a falta de um teto para que possam se isolar e materializar sua potencialidade para a inventividade. Isso, por consequência, torna os afazeres da casa inerentemente como um artifício que irá permear de forma substancial os escritos de autoria feminina, "pois as mulheres permaneceram dentro de casa por milhões de anos, então a essa altura até as paredes estão impregnadas com a sua força criativa, que de fato deve ter sobrecarregado [...] a capacidade dos tijolos [...] que precisa se atrelar a penas, pincéis, negócios e política" (WOOLF, 20I4, p. I26).

Nessa perspectiva, torna-se orgânica a presença no que se refere à aparição da comida nos escritos de autoria feminina. Sceats (2003) se apoia no discurso sócio-histórico e biológico sobre o ato de prover alimento enquanto lugar circunscrito ao feminino para afirmar que

Mulheres escrevem sobre comida e sobre comer. Mas porque isso ocorre? O corpo das mulheres possui a capacidade de produzir alimento para seus filhos, o que as categoriza como provedoras de nutrição, e na cultura ocidental as mulheres 
tradicionalmente carregam substancialmente o fardo de cozinhar e alimentar o outro, acarretando em implicações de poder e de ocupação (SCEATS, 2003, p. 2).

Um exemplo pertinente desse desdobramento pode ser observado no romance Como água para chocolate 10 (1993), que tem como proposta transformar esse lugar-comum que é imposto à mulher em um ambiente que proporcione a esse sujeito a possibilidade de uma nova perspectiva de sua existência a partir da ressignificação de códigos e sentidos que permeiam essa convenção social. Esquivel possui uma capacidade ímpar para incorporar em sua diegese o discurso gastronômico, e a partir dessa ficcionalização do modo de fazer e do consumo da comida problematizar a (i)materialidade do ser feminino. O cômodo da cozinha e as receitas nela preparadas se transformam numa linguagem simbólica e metafórica que não só promove o empoderamento (e às vezes a perpetuação da opressão patriarcal) dessas mulheres, mas também perpassa pelos conflitos socioculturais presentes no romance.

As doze receitas de tradicionais comidas mexicanas ditam o tom para a diegese, uma vez que tais receitas servem não só como divisores de capítulos da história de vida da protagonista - oferecendo ao romance a estrutura de um livro de receitas -, mas para mostrar como as mesmas serão relevantes para a jornada da protagonista, Tita De la Garza.

A princípio, a imersão de Tita na cozinha ocorre forma natural, como que por destino: como consequência do cortar das cebolas por Mamãe Elena, Tita ainda no ventre da mãe, tão sensível que já se mostrava em relação aos alimentos, chorou um rio de lágrimas que provocou a súbita antecipação do parto, e a personagem "[...] despencou neste mundo prematuramente, sobre a mesa da cozinha, entre os aromas de uma sopa de massinha que estava cozinhando, os do tomilho, do louro, do coentro, do leite fervido, do alho e, é claro, o da cebola" (ESQUIVEL, I993, p. 3-4). Podemos observar, a partir da introdução da personagem na narrativa, que se estabelece uma conexão singular entre Tita, o alimento e o espaço da cozinha - oferecendo à mesma uma qualidade que "[...] [rende] culto a Gastérea" (QUEIROZ, I994, p. 2I).

Entretanto, se Tita está interligada a esse espaço e ao que nele se produz, a personagem também nasce com um fardo a carregar. De acordo com a tradição da família De la Garza, por ser a filha mais nova e, sobretudo por ser mulher, Tita "[...] era a indicada para cuidar da mãe até o fim de seus dias" (ESQUIVEL, 1993, p. I2I). Por essa razão, Mamãe Elena se nega a criar qualquer vínculo com a sua filha. Esse distanciamento é demarcado na narrativa também a partir do nascimento da menina, pois no mesmo momento em que ela vem ao mundo o seu pai vem a óbito. Então "[i]mpactada, Mamãe Elena perdeu o leite", e "como nesse tempo não havia leite em pó [...] e não puderam conseguir uma ama-de-leite [...]" (ESQUIVEL, I993, p. 4) Nacha, cozinheira da família, acolhe Tita na cozinha para alimentá-la e partilha com a protagonista "os segredos da vida e do amor através da cozinha" (ESQUIVEL, I993, p. 198) e, ultimamente, acaba estabelecendo a personagem de uma vez por todas

"Women write about food and eating. Why should this be so? Women's bodies have the capacity to manufacture food for their infants which categorises them as feeders, and in western culture women have traditionally borne most of the burden of cooking for and nourishing others, with all that this implies of power and service".

Doravante iremos nos referir ao romance pela sigla CAPC.

"Gastérea é a décima musa: ela preside aos prazeres do gosto", afirma Brillat-Savarin (1995, p. 299). 


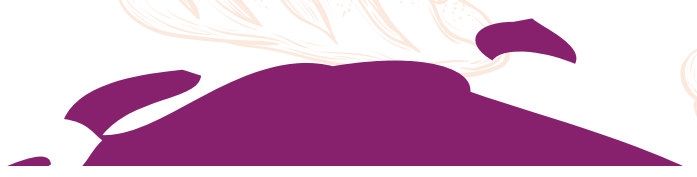

no espaço culinário sob a aprovação de Mamãe Elena. É a partir do compartilhamento do espaço da cozinha e do fazer culinário que Nacha proporciona a Tita o que sua mãe almeja tirar: autonomia para expressar a sua potencialidade criativa - e, por que não, artística - e a sua subjetividade através dessa nova linguagem proporcionada pela comida.

A partir dessa observação podemos perceber uma dupla ressignificação atribuída à cozinha pela autora mexicana: primeiramente, podemos compreender que o espaço em que Tita é inserida não é mais esse lugar do efêmero e destituído de empoderamento da mulher, como sugere Woolf (2014), mas agora se caracteriza como um espaço de refúgio onde é possível encontrar proteção e conhecimento; é relevante considerar também que a cozinha, desde o primeiro capítulo do romance, é constituída como um espaço propício ao florescimento da criatividade em consonância com a experiência coletiva representada por Nacha - e, posteriormente como as outras personagens da narrativa -, promovendo um ambiente de sororidade ${ }^{12}$, um dado intrínseco à linguagem culinária como aponta Montanari (2013): "Em todos os níveis sociais, a participação na mesa comum é o primeiro sinal de pertencimento ao grupo. Esse pode ser a família, mas também uma comunidade mais ampla [...]" (p. I59).

Ainda sobre a tradição familiar mantida por Mamãe Elena, ela mesma ganha peso na narrativa quando o então namorado de Tita, Pedro Muzquiz, deseja pedir a mão da moça em casamento. Todavia, Mamãe Elena sequer permite que o rapaz realize o pedido e lembra a Tita: "Pois mais vale que lhe informes que se é para pedir tua mão, não o faça. Perderia seu tempo e me faria perder o meu. Sabes muito bem que por ser a mais jovem das mulheres te corresponde cuidar de mim até o dia de minha morte" (ESQUIVEL, I993, p. 8). Não contente em negar a Tita a chance de se casar com o amor de sua vida, Mamãe Elena oferece a mão de sua outra filha, Rosaura, a Pedro - sendo que o último aceita a proposta da matriarca com a justificativa de "[casar-se] sentindo um imperecível amor por Tita" (ESQUIVEL, I993, p. I2), usando seu enlace com Rosaura para continuar próximo a amada. Ademais, Mamãe Elena ainda encarrega Tita das preparações culinárias da festa de casamento de Pedro e Rosaura "[...] como castigo por não ter querido estar presente no dia em que foram pedir a mão de sua irmã Rosaura, pretextando uma enxaqueca” (ESQUIVEL, I993, p. 2I). É pertinente levar em consideração este momento da diegese por nos possibilitar perceber que Mamãe Elena é colocada numa posição que acaba por perpetuar a opressão patriarcal naquele espaço, visto que ela opera de modo a subjugar os seus - Tita especialmente - para manter a estabilidade do seu poder e das suas ordens. A autora, ao atribuir caráter opressor a uma personagem feminina, rompe com a impressão socialmente estabelecida de que, quando se fala sobre a sociedade patriarcal e seu despotismo para com o sujeito feminino, apenas as práticas masculinas perpetuam essa relação desigual de poder e expõe para seus leitores que as práticas femininas também podem reificar esse "pacto social" e capitalizar as práticas de opressão-confinamento.

Aqui nos apropriamos do termo sororidade não como "[...] uma concepção que foi embutida de que as mulheres, sendo todas iguais, deveriam lutar contra a desigualdade em relação aos homens" (SILVA, 2009, p. 48), mas como a prática entre mulheres dos mais diversos segmentos raciais, étnicos, etc., que almejam o estabelecimento de uma coalizão sociopolítica com seus pares, na intenção de fortificar o combate contra a opressão patriarcal sistematizada e a favor da emancipação do sujeito mulher.

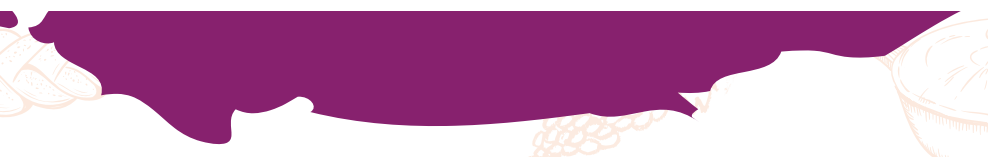


Nos aliamos ao geógrafo sino-americano Yi-Fu Tuan e a sua obra Landscapes of fear (2013) para observar que, durante a narrativa, ao passo em que Mamãe Elena percebe em Tita os primeiros sinais de obstinação para com suas regras, a matriarca da família De la Garza utiliza o confinamento como forma de "impor ordem ou prevenir os danos do caos interno [...], isolando [esse dano] num espaço, dessa forma tornando-o inócuo" ${ }^{13}$ (TUAN, 2013, p. I87), tornando, finalmente, Tita em um sujeito que vive à margem da sociedade representada pelo rancho dos De la Garza. Sendo assim, notamos que Esquivel em sua inventividade concebe uma representação da realidade mexicana do século XX onde, apesar da presença masculina ser notoriamente secundária, a perpetuação do machismo e do enclausuramento no espaço doméstico é bastante transparente, visto que "[...] Mamãe Elena personifica a ordem patriarcal. Sua família [...] pode ser entendida como um microcosmo do patriarcado mexicano [em que a] obediência é altamente importante, e questionar a autoridade familiar leva a penalidades severas e à reprovação" ${ }^{14}$ (SCHNEIDER, J., 20IO, p. 83).

Uma vez que Tita é marginalizada e silenciada por Mamãe Elena no âmbito da cozinha, ela encontra subterfúgio no ato de cozinhar e de escrever seu livro de receitas, uma vez que o confinamento é visto aqui duplamente como "[...] um lugar de punição assim como é visto como um lugar para a redenção" ${ }^{15}$ (TUAN, 2013, p. I89). Percebemos a ênfase na equivalência entre a arte de cozinhar e a arte do fazer literário proposto por Esquivel quando a narradora afirma que "[...] assim como um poeta brinca com as palavras, assim ela brincava prazerosamente com os ingredientes e com as quantidades, obtendo resultados fenomenais" (ESQUIVEL, I993, p. 56). Podemos notar que, a partir da comparação entre Tita e um poeta, compreende-se que o ato de cozinhar (escrever) torna-se uma maneira da personagem manifestar a sua subjetividade (assim como um poeta e o seu uso das palavras), configurando-se assim como uma forma de resistência-existência às convenções sociais que lhe foram impostas através da tradição familiar, que lhe nega a possibilidade de expressão dos sentimentos. E se a comida vai além do ato de nutrir, mas caracteriza-se também como uma forma de expressão (QUEIROZ, 1994), faz-se relevante trazer a relação entre o ato do fazer gastronômico como forma de manifestação linguística proposta por Carteau, Giard e Mayol (1996) que reforçam a equivalência do fazer culinário ao ato de escrever ao afirmarem que essa arte da existência-resistência é o que configura a composição subjetiva e potente do feminino:

[...] a restituição, através dos gestos, dos sabores e das composições, de uma legenda muda, como se, por força de assumi-la com meu corpo e minhas mãos, eu devia chegar a restaurar-lhe a alquimia, a merecer-lhe o segredo da língua, como se, deste pisar obstinado na terra-mãe, um dia acabaria recuperando a verdade da palavra" (CERTEAU; GIARD; MAYOL, I996, p. 215, grifo dos autores).

"imposing order or forestalling the dangers of internal chaos [...], [said danger] is isolated in space, thereby rending it innocuous".

“[...] Mamá Elena personifies the patriarchal order. Her family [...] can be understood as a microcosm of Mexican patriarchy [where] obedience is highly important, and questioning the parental authority leads to severe penalties and disapproval"

"[...] a place of punishment it also saw it as a place for redemption". 
Nessa perspectiva, o espaço da cozinha (e o que nele é produzido) toma a forma de uma reverberação linguística que simbolicamente corresponde tanto ao comportamento de Tita diante as adversidades impostas naquela comunidade opressora, como uma forma de representar e materializar seus desejos e sentimentos reprimidos pela mãe. Este dado torna-se evidente na sua relação com Pedro, seu grande amor e esposo de sua irmã, Rosaura. A descrição do primeiro encontro de Tita e Pedro, em uma festa de Natal recepcionada por amigos da família De la Garza, nos diz que, no momento em que o olhar da protagonista encontrou com o do seu então pretendente, ela "[...] compreendeu perfeitamente o que deve sentir a massa de um filhó ao entrar em contato com o azeite fervendo. Era tão real a sensação de calor que invadia todo o seu corpo que [...], como num filhó, começassem a lhe brotar borbulhas por todo o corpo [...]" (ESQUIVEL, I993, p. I3). Podemos identificar, a partir deste exemplo, além da função estética da comida enquanto artifício metafórico, que ela funciona como um alicerce que concretiza sentimentos metafísicos no universo de Tita, que se torna perceptível através desses códigos desde a mais tenra idade devido à sua imersão no espaço da cozinha. Não apenas isso, mas podemos entender que o universo de Tita, numa perspectiva do universo da autora, é expandido, estabelecendo que ambas, Esquivel e Tita, compõem um universo metafísico para a própria escrituração da metafísica histórica do sujeito feminino no México.

Assim sendo, torna-se natural que o vínculo de Tita com esse espaço também lhe permita manifestar seus sentimentos através do fazer culinário em associação à sua potencialidade inventiva, uma vez que já foi estabelecido no romance que a comida e o espaço da cozinha se configuram como ressignificação da linguagem e das expressões das quais a personagem foi destituída. Sobre essa analogia entre linguagem e comida, Montanari (20I3) afiança que "[a analogia] dá a ambas a conotação de códigos de comunicação, que [...] transmitem valores simbólicos e significados de natureza variada [...]" (p. I83, grifo do autor).

Tal afirmação se torna evidente quando, na narrativa, Nacha vai a óbito logo após a festa do casamento de Rosaura e Pedro e Tita fica responsável pelos afazeres da cozinha a mando de Mamãe Elena, numa tentativa de afastá-la de vez de Pedro. O rapaz, no entanto, não satisfeito com as regras da matriarca, "[...] pensou que seria de bom alvitre levar-lhe um ramo de rosas ao cumprir seu primeiro ano como cozinheira do rancho" (ESQUIVEL, I993, p. 38). Percebendo a consternação que tal gesto causou a Rosaura, Mamãe Elena ordena a Tita que jogue fora as rosas recebidas. Decidida a não se desfazer do presente do amado, Tita rememora "uma receita pré-hispânica onde se utilizam pétalas de rosas" (ESQUIVEL, I993, p. 39) que Nacha a ensinara e que, apesar de ser feita com faisão, a cozinheira faz uso da única ave que tinha a sua disposição: codornas - consideradas popularmente como uma iguaria afrodisíaca. Ao se furar nos espinhos, o sangue de Tita mescla-se com o molho de rosas que acompanha as codornas, potencializando o poder afrodisíaco do prato e causando efeitos diversos em todos que estavam à mesa, sendo que o mais inesperado foi causado em Gertrudis, irmã mais velha de Tita: 
em Tita, porém ela estava ausente, com o corpo sobre a cadeira, sentado, muito aprumadamente, é claro, mas sem nenhum sinal de vida nos olhos. Desse jeito parecia que num estranho fenômeno de alquimia seu ser tivesse se dissolvido no molho das rosas, no corpo das codornas, no vinho e em cada um dos odores da comida. Desta maneira penetrava no corpo de Pedro, voluptuosa, aromática, ardente, completamente sensual. Parecia que tinha descoberto um código novo de comunicação no qual Tita era a emissora, Pedro o receptor e Gertrudis a felizarda em quem se sintetizava esta singular relação sexual, através da comida (ESQUIVEL, I993, p. 4I-2).

Trazemos essa extensa citação para demonstrar como Esquivel ressalta, em Como água para chocolate, a maneira com que a forte reação das personagens, causada pelo manjar preparado por Tita, concretiza a paixão transcendente que a protagonista sente por Pedro e que, impedida de expressar por meios comuns, encontra na cozinha e na culinária um novo código de comunicação que a permite desenvolver uma resistência às amarras da opressão da sua mãe. Se, segundo Foucault (1997), o ato de se negar a seguir o que é imposto ao sujeito é a forma mais essencial e determinante de resistência, então "[...] resistir não é simplesmente uma negação, mas um processo criativo; um processo de criar e recriar, de mudar a situação, de ser um sujeito ativo desse processo [de mudança]" ${ }^{16}$ (FOUCAULT, I997, p. I68). Para Tita, essa inovadora possibilidade de expressar seus sentimentos por Pedro sem a interferência da força opressora de Mamãe Elena, a partir de um ato de resistência gastronômica, faz com que a personagem reconheça a sua própria potência enquanto sujeito - já que a cozinha se configura como um mundo-cosmo - incentivando-a a reproduzir mais receitas que lhe foram ensinadas por Nacha para manter seus afetos por Pedro que a mãe tenta abolir. Essa nova dinâmica reverbera de forma significativa no romance, visto que a imprescindibilidade sentida por Tita de cozinhar cada vez mais para manter vivo o seu relacionamento com Pedro a leva a escrever um livro de receitas, no qual incorpora as suas vivências que se relacionam diretamente a cada prato, dando um caráter metaficcional ao romance de Esquivel.

Finalmente, é igualmente interessante perceber como, ao modificar os ingredientes da receita pré-hispânica e acrescentar - mesmo que acidentalmente - o seu próprio sangue, Tita revela a sua natureza subversiva e não conformista perante as ordens e as tradições, colocando em prática o seu próprio empoderamento contra uma tradição que lhe foi imposta. Assim sendo, podemos apreender que, através da recriação da receita da codorna com rosas - tal como as receitas subsequentes - a autora mexicana oferece ao seu romance também uma ressignificação dos modos de comunicação e de intervenção no e do espaço da cozinha, "[...] convertendo-o em espaço dinâmico e sempre móvel, que se transforma e evolui ao longo do curso narrativo" 17 (ZUBIAURRE, 2000, p. I59); ou seja, através da escrita de Esquivel, não só o significado da cozinha é transformado, mas ele transforma aqueles inseridos nesse espaço.

"[...] to resist is not simply a negation but a creative process; to create and recreate, to change the situation, actually to be an active member of that process".

"[...] se convierte em espacio dinámico y siempre cambiante, con un significado que se transforma y evoluciona a lo largo del transcurso narrativo". 


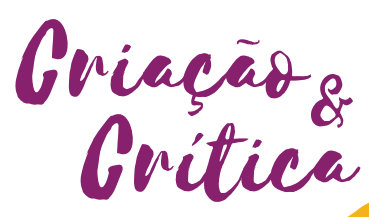

\section{Consideraçöes firais}

Embora pareça um tanto inusitado, num primeiro instante, que um romance que problematize as noções de ordem, tradição, e empoderamento feminino - como pudemos perceber na discussão pautada acima - insira a sua protagonista no espaço da cozinha, CAPC pretende metamorfosear este espaço, historicamente opressor e destinado ao confinamento, em um espaço conivente para com as manifestações da potência do sujeito feminino e a ruptura das normas. Assim, a cozinha se torna um relevante espaço de representação do sujeito feminino - como, de fato, "teto todo seu" -, onde sua subjetividade pode aflorar em consonância com sua criatividade e liberdade artística. O fazer culinário, deste modo, acaba por ressignificar as experiências das personagens femininas no romance, pois é da cozinha de onde surgem as estratégias de expressão e de resistência.

Em seu romance, Esquivel utiliza o tropo da cozinha para reavaliar os tradicionais papéis assumidos pela mulher - seja na arte, seja na sociedade -, em especial no contexto que permeia o romance, em que se espera que o sujeito mulher, aqui representado por (não só, mas também) Tita e perpetuado por Mamãe Elena, seja a personificação da figura do Anjo do Lar mencionado por Woolf no seu ensaio Profissão para mulheres (2015): "Ela era extremamente simpática. Imensamente encantadora. Totalmente altruísta. Excelente nas difíceis artes do convívio familiar. Sacrificava-se todos os dias. [...], seu feitio era nunca ter opinião ou vontade própria, [...]. E acima de tudo [...] ela era pura” (p. II-2).

Apesar da escolha singular de utilizar a comida, sua preparação e o espaço da cozinha - uma atividade que perpetua alguns dos estereótipos nocivos à imagem da mulher -, é através da capacidade inventiva e da potencialidade estética da escrita de Laura Esquivel que a autora transcreve esse espaço de confinamento, de opressão, mas também de potência, de libertação, de emancipação e, acima de tudo, de transformação e de prazer.

\section{Referências bibliográficas}

Adichie, Chimamanda Ngozi. Sejamos todos feministas. Trad. Christina Baum. São Paulo: Companhia das Letras, 2015.

BonnicI, Thomas. Teoria e crítica literária feminista: conceitos e tendências. Maringá: Eduem, 2007.

Bourdieu, Pierre. A dominação masculina. Trad. Maria Helena Kühner. Rio de Janeiro: Bertrand Brasil, 2015.

Brillat-SaVArin, Jean-Anthelme. A fisiologia do gosto. Trad. Paulo Neves. São Paulo: Companhia das Letras, 1995.

Certeau, Michel de; Giard, Lucy; Mayol, Pierre. A invenção do cotidiano; 2. morar, cozinhar. Trad. Ephraim F. Alves e Lucia Endlich Orth. Petrópolis: Vozes, 1996.

EsQuivel, Laura. Como água para chocolate. Trad. Olga Davary. São Paulo: Martins Fontes, 1993. . A lei do amor. Trad. Eduardo Brandão. São Paulo: Martins Fontes, 1996. 


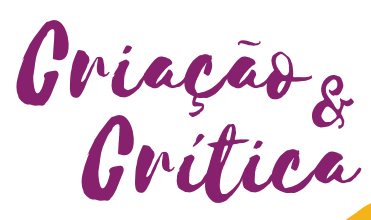

. Tão veloz como o desejo. Rio de Janeiro: Objetiva, 200I.

. Malinche. Trad. Léo Schlafman. Rio de Janeiro: Ediouro, 2007.

. Intimas suculencias: tratado filosófico de cocina. Ciudad Autónoma de Buenos Aires: Aguilar, Altea, Taurus, Alfaguara, 20I4.

Foucault, Michel; Rabinow, Paul (ed.). Ethics: subjectivity and truth. Trad. Robert Hurley. New York: The New Press, 1997.

HaLEY, Andrew P. Turning the tables: restaurants and the rise of the American middle class, I880-I920. Chapel Hill: The University of North Carolina Press, 2013.

Montanari, Massimo. Comida como cultura. Trad. Letícia Martins de Andrade. 2. ed. São Paulo: Editora Senac São Paulo, 2013.

O’neill, Molly. At Dinner With Laura Esquivel; Sensing the spirit in all things, seen and unseen. Disponível em: http://www.nytimes.com/I993/03/3I/garden/at-dinner-with-laura-esquivel-sensing-the-spirit-in-all-things-seen-and-unseen.html?pagewante$\mathrm{d}=$ all. Acessado em: 03 de dezembro de 2016.

Perrot, Michelle. Minha história das mulheres. Trad. Angela M. S. Corrêa. São Paulo: Contexto, 2007 .

QueIroz, Maria José de. A literatura e o gozo impuro da comida. Rio de Janeiro: Topbooks, I994.

SAndoval, Anna Marie. Toward a latina feminism of the Americas: repression \& resistance in chicana \& mexicana literature. Texas: University Press of Texas, 2008.

SCEATS, Sarah. Food, consumption and the body in contemporary women's fiction. Cambridge: Cambridge University Press, 2003.

SCHNEIDER, Julia Maria. Recreating the image of women in Mexico: a genealogy of resistance in mexican narrative set during the revolution. 20I0. $138 \mathrm{f}$. Tese - The Department of Foreign Languages and Literatures, Louisiana State University, Louisiana, 2010.

SCHNEIDER, Liane. "Quem fala como mulher na literatura de mulheres?" In: CAVALCANTI, Ildney; Lima, Ana Cecília; SchineIder, Liane (org.). De mulher às mulheres: dialogando sobre literatura, gênero e identidades. Maceió: EDUFAL, 2006.

SILVA, Jacicarla Souza da. Vozes femininas da poesia latino-americana: Cecília e as poetisas uruguaias. São Paulo: Editora UNESP; São Paulo: Cultura Acadêmica, 2009.

TuAn, Yi-Fu. Espaço e lugar: a perspectiva da experiência. Trad. Lívia de Oliveira. Londrina: Eduel, 20I3.

. Landscapes of fear. Minnesota: University of Minnessota Press, 2013.

WoodWARD, Kathryn. "Identidade e diferenças: uma introdução conceitual”. In: SILVA, Tomaz Tadeu (org). Identidade e diferença: a perspectiva dos Estudos Culturais. Petrópolis: Vozes, 2000.

Woolf, Virginia. Um teto todo seu. Trad. Bia Nunes de Sousa, Glauco Mattoso. I. ed. São Paulo: Tordesilhas, 20I4.

. "Profissão para mulheres". In: Profissão para mulheres e outros artigos feministas.

Trad. Denise Bottmann. Porto Alegre: L\&PM, 2015. 
Zubiaurre, María Teresa. El espacio en la novela realista: paisajes, miniaturas, perspectivas. Mexico: Fondo de Cultura Económica, 2000.

Recebido em: 30/03/2017

Aceito em: 10/05/2017

Referência eletrônica: Marinho Lucio, Ana Cristina; SAntos, Jenison Alisson. Opressão e resistência na cozinha em Como água para chocolate, de Laura Esquivel. Revista Criação E Crítica, São Paulo, n. I8, p. I38-I5I, jun. 20I7. Disponível em: <http://www.revistas.usp. $\mathrm{br} /$ criacaoecritica>. Acesso em: dd/mm/aaaa. 